\title{
Substituted Pyrroles
}

\author{
N. Zh. Mamardashvili*, M. E. Kluyeva and O. A. Golubchicov \\ Institute of Solution Chemistry of the Russian Academy of Sciences, 153045 Academicheskaya, 1, \\ Ivanovo, Russia \\ E-mail:ngm@ihnr.polytech.ivanovo.su
}

* Author to whom correspondence should be addressed.

Received: 14 December 1999 / Accepted: 22 January 2000 / Published: 26 January 2000

Abstract: A stepwise synthesis of $\alpha$-unsubstituted pyrroles with desired substituents in the $\beta$-positions of the ring has been devised.

Keywords: pyrroles, $\beta$-substitued.

\section{Introduction}

Pyrrole synthesis depends strongly on the nature and relative position of the substituents in the molecule. The methods permitting the synthesis of comparatively simple pyrroles are found to be useless for more complex structures. This paper describes the synthesis of a series of pyrrole derivatives (1-5).

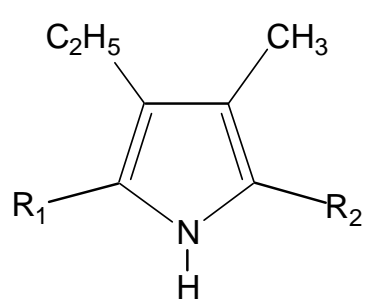

Figure 1. $\mathrm{R}_{1}=\mathrm{CH}_{3}(\mathbf{1}, \mathbf{6}), \mathrm{COOC}_{2} \mathrm{H}_{5}(\mathbf{2 - 5}) ; \mathrm{R}_{2}=\mathrm{COOCH}_{2} \mathrm{C}_{6} \mathrm{H}_{5}(\mathbf{1}, \mathbf{2}), \mathrm{COOH}(\mathbf{3}), \mathrm{I}(\mathbf{4}), \mathrm{H}(\mathbf{5}), \mathrm{COOC}_{2} \mathrm{H}_{5}(\mathbf{6})$.

(C) 2000 by MDPI (http://www.mdpi.org). Reproduction is permitted for noncommercial purposes. 
Relatively accessible $\alpha$-ethoxycarbonylpyrroles are obtained by the condensation of the corresponding alkylpentanediones with nitrosoacetoacetic ester in acetic acid with the reduction [1-8]. However $\alpha$-unsubstituted pyrroles - the desired product of the synthesis - have a great disadvantage: they contain large substituents in adjacent $\beta$-positions responsible for extra restrictions during condensation. We now report a method that allows the synthesis of structures with these large substituents in the desired positions while excluding the steric factor influence on pyrrole reactivity.

\section{Results and Discussion}

2,4-Dimethyl-3-ethyl-5-benzyloxycarbonylpyrrole (1) was prepared by reaction of 2,4-dimethyl-3ethyl-5-ethoxycarbonylpyrrole (6) with benzyl alcohol. 2-Ethoxycarbonyl-3-ethyl-4-methyl-5benzyloxycarbonylpyrrol (2) was prepared by oxidizing the $\alpha$-methyl group of (1) with sulfuryl chloride and treatment with ethanol. Reduction of (2) with hydrogen over palladium catalyst yields 2ethoxycarbonyl-3-ethyl-4-methyl-5-carboxypyrrole (3). Decarboxylation was carried out in two stages. At first the carboxy-group was substituted by iodine to form 2-ethoxycarbonyl-3-ethyl-4-methyl-5iodopyrrole (4) and then the iodine was removed with $\mathrm{SnCl}_{2}$. This sequence gives 2-ethoxycarbonyl-3ethyl-4-methylpyrrole (5) in adequate yield. (6) is the key compound in the synthesis of many di- and tetra-pyrrole compounds of linear and cyclic structure.

To confirm the molecular structures the IR spectra of the synthesized pyrroles were investigated (Table 1). Together with NMR data, in most cases they reliably prove the presence of the functional groups in the molecules.

\section{Experimental}

General Methods and Materials

${ }^{1} \mathrm{H}$ nuclear magnetic resonance spectra were recorded on a Bruker AC-500 spectrometer operating at $600 \mathrm{MHz}$ with HMDS as internal standard in deuterochloroform. IR spectra were obtained on a Specord M80 spectrophotometer in KBr tablets. 2,4-Dimethyl-3-ethyl-5-ethoxycarbonylpyrrole (6) was synthesized by a known method [2].

\section{2,4-Dimethyl-3-ethyl-5-benzyloxycarbonylpyrrole (1)}

2,4-Dimethyl-3-ethyl-5-ethoxycarbonylpyrrole $(6,10 \mathrm{~g})$ in benzyl alcohol $(50 \mathrm{~mL})$ were placed into a flask equipped with a distilling column, Liebig condenser and dropping funnel. The solution was heated to boiling temperature and then a solution of sodium $(0.2 \mathrm{~g})$ in benzyl alcohol $(100 \mathrm{~mL})$ was added to the flask. After all the ethanol was distilled off the reaction mixture was cooled, diluted with water $(200 \mathrm{~mL})$ and then acidified with acetic acid. The resulting precipitate was isolated by filtration and recrystallized from ethanol. Yield $87 \%$, melting point $166-168^{\circ} \mathrm{C}$, NMR: 8.89 (s, $\left.1 \mathrm{H}, \mathrm{NH}\right), 7.34$ 
$\left(\mathrm{m}, 5 \mathrm{H}, \mathrm{C}_{6} \mathrm{H}_{5}\right), 4.22\left(\mathrm{~m}, 2 \mathrm{H}, \mathrm{OCH}_{2} \mathrm{Ph}\right), 2.27$ (q, 2H, $\left.\underline{\mathrm{CH}}_{2} \mathrm{CH}_{3}\right), 2.21\left(\mathrm{~s}, 3 \mathrm{H}, 2-\mathrm{CH}_{3}\right), 2.09$ (s, 3H, 4- $\left.\mathrm{CH}_{3}\right)$, $0.84\left(\mathrm{t}, 3 \mathrm{H}, \mathrm{CH}_{2} \underline{\mathrm{CH}}_{3}\right)$

\section{2-Ethoxycarbonyl-3-ethyl-4-methyl-5-benzyloxycarbonylpyrrole (2)}

Freshly distilled sulfuryl chloride $(8.9 \mathrm{~mL})$ was added to a solution of 2,4-dimethyl-3-ethyl-5benzyloxycarbonylpyrrol $(1,9 \mathrm{~g})$ in dry ether $(100 \mathrm{~mL})$ while the reaction mixture temperature was kept below $20^{\circ} \mathrm{C}$. The mixture was kept overnight at room temperature and then the ether was evaporated. Ethanol $(150 \mathrm{~mL})$ was added to the residuum. After 1 hour the solution was diluted with water $(200 \mathrm{~mL})$. The organic phase was extracted with ether and washed with water. The ether was evaporated and the resulting product was recrystallized from ethanol. Yield 92\%, melting point 51-53 ${ }^{\circ} \mathrm{C}$, NMR: $8.88(\mathrm{~s}, 1 \mathrm{H}, \mathrm{NH}), 7.36\left(\mathrm{~m}, 5 \mathrm{H}, \mathrm{C}_{6} \mathrm{H}_{5}\right), 4.32\left(\mathrm{~m}, 2 \mathrm{H}, \mathrm{OCH}_{2} \mathrm{Ph}\right), 4.13\left(\mathrm{q}, 2 \mathrm{H}, \mathrm{OCH}_{2} \mathrm{CH}_{3}\right), 2.69$ (q, $\left.2 \mathrm{H}, \underline{\mathrm{CH}}_{2} \mathrm{CH}_{3}\right), 2.24\left(\mathrm{~s}, 3 \mathrm{H}, 4-\mathrm{CH}_{3}\right), 1.27\left(\mathrm{t}, 3 \mathrm{H}, \mathrm{OCH}_{2} \underline{\mathrm{CH}}_{3}\right), 0.84\left(\mathrm{t}, 3 \mathrm{H}, \mathrm{CH}_{2} \underline{\mathrm{CH}}_{3}\right)$.

\section{2-Ethoxycarbonyl-3-ethyl-4-methyl-5-carboxypyrrole (3)}

Hydrogen was passed through a stirred mixture of 2-ethoxycarbonyl-3-ethyl-4-methyl-5benzyloxycarbonylpyrrole $(2,10 \mathrm{~g})$, activated $10 \% \mathrm{Pd} / \mathrm{C}(2 \mathrm{~g})$, tetrahydrofuran $(200 \mathrm{~mL})$ and triethylamine $(2 \mathrm{~mL})$ over 6 hours. Then the solution was evaporated down to $50-\mathrm{mL}$ residual volume and methanol $(100 \mathrm{~mL})$ was added. After evaporating the remaining tetrahydrofuran the methanol solution was cooled. The resulting precipitate was isolated by filtration and washed with methanol, then ether and hexane. Yield 96\%, melting point 186-188 ${ }^{\circ} \mathrm{C}$, NMR: 9.38 (s, 1H, NH), 4.17 (q, $2 \mathrm{H}, \mathrm{OCH}_{2} \mathrm{CH}_{3}$ ), 2.69 (q, $\left.2 \mathrm{H}, \underline{\mathrm{CH}}_{2} \mathrm{CH}_{3}\right), 2.24\left(\mathrm{~s}, 3 \mathrm{H}, 4-\mathrm{CH}_{3}\right), 1.32\left(\mathrm{t}, 3 \mathrm{H}, \mathrm{OCH}_{2} \underline{\mathrm{CH}}_{3}\right), 0.87$ (t, 3H, $\left.\mathrm{CH}_{2} \underline{\mathrm{CH}}_{3}\right)$.

\section{2-Ethoxycarbonyl-3-ethyl-4-methyl-5-iodopyrrole (4)}

A solution of sodium bicarbonate $(4.5 \mathrm{~g})$ in water $(80 \mathrm{~mL})$ was added dropwise to a stirred solution of 2-ethoxycarbonyl-3-ethyl-4-methyl-5-carboxypyrrole $(3,5 \mathrm{~g})$ in ethanol $(100 \mathrm{~mL})$. Then the solution was filtered and a solution of iodine $(4.6 \mathrm{~g})$ and $\mathrm{KI}(5.9 \mathrm{~g})$ in water $(50 \mathrm{~mL})$ was added to the filtrate with stirring at $60^{\circ} \mathrm{C}$. Stirring was continued for another 10 minutes and then the reaction mixture was diluted with water $(100 \mathrm{~mL})$. The resulting precipitate was isolated by filtration. Yield $86 \%$, melting point 119-120 ${ }^{\circ} \mathrm{C}, \mathrm{NMR}: 8.90$ (s, $\left.1 \mathrm{H}, \mathrm{NH}\right), 4.21$ (q, $2 \mathrm{H}, \mathrm{OCH}_{2} \mathrm{CH}_{3}$ ), 2.67 (q, $2 \mathrm{H}, \underline{\mathrm{CH}}_{2} \mathrm{CH}_{3}$ ), 1.90 (s, 3H, 4- $\left.\mathrm{CH}_{3}\right), 1.28\left(\mathrm{t}, 3 \mathrm{H}, \mathrm{OCH}_{2} \underline{\mathrm{CH}}_{3}\right), 0.86\left(\mathrm{t}, 3 \mathrm{H}, \mathrm{CH}_{2} \underline{\mathrm{CH}}_{3}\right)$.

\section{2-Ethoxycarbonyl-3-ethyl-4-methylpyrrole (5)}

Hydrochloric acid $(100 \mathrm{~mL})$ was added to a boiling solution of 2-ethoxycarbonyl-3-ethyl-4-methyl5-iodopyrrole $(4,5 \mathrm{~g}), \mathrm{SnCl}_{2}(8.5 \mathrm{~g})$ and $\mathrm{KI}(0.8 \mathrm{~g})$ in ethanol $(350 \mathrm{~mL})$. The organic phase was extracted with ether and washed with water. The ether was evaporated under vacuum at room tempera- 
ture. Yield 87\%, melting point 22-24 $4^{\circ}$, NMR: 8.94 (s, $\left.1 \mathrm{H}, \mathrm{NH}\right), 4.20$ (q, $\left.2 \mathrm{H}, \mathrm{OCH}_{2} \mathrm{CH}_{3}\right), 2.68(\mathrm{q}, 2 \mathrm{H}$, $\left.\underline{\mathrm{CH}}_{2} \mathrm{CH}_{3}\right), 1.94\left(\mathrm{~s}, 3 \mathrm{H}, 4-\mathrm{CH}_{3}\right), 1.29\left(\mathrm{t}, 3 \mathrm{H}, \mathrm{OCH}_{2} \underline{\mathrm{CH}}_{3}\right), 0.87$ (t, 3H, $\left.\mathrm{CH}_{2} \underline{\mathrm{CH}}_{3}\right)$

Table 1. Infrared spectra of pyrroles (1-5), $\mathrm{cm}^{-1}$.

\begin{tabular}{|c|c|c|c|c|c|c|c|}
\hline $\mathbf{1}$ & $\gamma(\mathrm{NH})$ & $\gamma(\mathrm{CH})$ & $\delta(\mathrm{CH})$ & $\gamma(\mathrm{CH})$ & $\mathrm{C}-\mathrm{C}$ & $\mathrm{C}=\mathrm{O}$ & $\mathrm{C}-\mathrm{O}$ \\
\hline $\mathbf{6}$ & 3456 & - & 1379 & 1022 & 1348, & 1664 & 1290 \\
& & & & & 1510 & & \\
$\mathbf{1}$ & 3450 & 3100, & 1380 & 1010 & 1360, & 1670 & 1280 \\
& & 3138 & & & 1530 & & \\
$\mathbf{2}$ & 3451 & 3100, & 1380 & 1015 & 1338, & 1690 & 1287 \\
& & 3140 & & & 1514 & & \\
$\mathbf{3}$ & 3450 & - & 1377 & 1090 & 1328, & 1685 & 1273 \\
& & & & & 1517 & & \\
$\mathbf{4}$ & 3462 & & 1384 & 1116 & 1390, & 1687 & 1268 \\
& & & & & 1517 & & \\
$\mathbf{5}$ & 3450 & 3112 & 1382 & 1000 & 1357, & 1680 & 1295 \\
& & & & & 1578 & & \\
\hline
\end{tabular}

\section{References and Notes}

1. Jackson, A.H.; Kenner, G.W.; Wass J. J.Chem.Soc., Perkin Trans I 1972, 1475-1478.

2. Baldwin, J.E.; Crossley, M.J.; Klose I. Tetrahedron 1982, 38, 1475-1478.

3. Ogoshi, H.; Sugimoto, H.; Nishiguchi, E. J. Am. Chem. Soc. 1983, 105, 2699-2703.

4. Callot, H.J.; Tshamber, T. J. Org. Chem. 1977, 42, 1567-1570.

5. Iurgen, W.; Heinz, S.A. Tetrahedron Lett. 1985, 25, 6059-6062.

6. Wijesekera, T.P.; Paine, J.B.; Dolphin, D. J. Am. Chem. Soc. 1983, 105, 6449-6747.

7. Sessler, J.L.; Hugdaht, J.; Jonson, M.R. J. Org. Chem. 1986, 51, 2838-2840.

8. Sessler, J.L.; Jonson, M.R. Angew. Chem. 1987, 99, 679-680.

Samples Availability: available from the authors and MDPI.

(C) 2000 by MDPI (http://www.mdpi.org). Reproduction is permitted for noncommercial purposes. 